\title{
Péter Kiszl
}

Eötvös Loránd University in Budapest, Hungary. Faculty of Humanities

e-mail: kiszl.peter@btk.elte.hu

ORCID ID: 0000-0003-2992-295X

\section{hipping information in Hungary - a library- oriented diachronic perspective on the past,}

\section{present and future}

\author{
DOI: http://dx.doi.org/10.12775/FT.2019.003
}

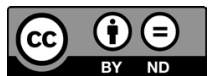

The text is available under a Creative Commons Attribution-NoDerivatives 4.0 International (CC BY-ND 4.0).

Péter, Kiszl, Librarian and Economist, PhD, habil., Associate Professor at Eötvös Loránd University, Budapest, Hungary. He is director of the Institute of Library and Information Science (LIS), head of the Department of Information Science, director of the LIS PhD Programme, head of the LIS BA and MA programmes, director of the Centre for Digital Humanities, chair of the Board of Trustees of the University Library Foundation, member of the Management Committee of Distant Reading for European Literary History of the EU-funded European Cooperation in Science and Technology Programme (COST Action CA16204) and member of the Editorial Board of the International Journal of Digital Humanities (Springer Nature). His research interests include information and knowledge management, business information, entrepreneurship development of training in LIS and digital humanities.

ummary. Aim: The aim of this paper is to introduce the evolutionary process of information service tools used in libraries through the system of Hungarian information sources on shipping. In the first part we describe a possible model for collecting, identifying, analysing and publishing Hungarian scientific literature on shipping. In the next part we describe the current situation in Hungary, especially regarding content accessible online for free, published by public administration bodies, and professional and non-governmental organizations. Finally, we discuss possible future courses of development. Research method: Our research is based on scientific literature, professional consultations, our own data collection, and experiences. Our work, especially the identification and use of documents and modern infocommunicational applications, is largely based on selection and assessment performed during library information service, on systems approach, and on looking for connections. We aimed to use English references in the paper, but in those cases where no such sources were found, and it was necessary for understanding the point, we listed Hungarian bibliographic entries. Results/Conclusions: The development of information service systems related to shipping and aimed at current events is inconceivable without involving the latest IT innovations, the cooperation of different fields, and the support networks of the European Union. The future is services providing aggregated, multi-criteria searching. Other nations can draw inspiration from analysing Hungary's developmental curve and trends to meet both the scientific 
and the everyday needs for sources in the field. Moreover, this paper can help Hungarian developments to be linked with further international information systems.

\section{Introduction}

Shipping has been an essential part of our lives for ages. This transport sector, which is older than railways and public roads, will never lose its relevance. Therefore, it is crucial to be aware of document sources related to the past, present, and future, and their interconnections. The aim of this paper is to provide an overview of the information service tools of this specific field in an international context. We aimed to achieve this by outlining a development curve of tasks mostly for the fields of history, literature, library services, and IT, and of the plans on discovering the Hungarian past, the present status, and the development opportunities for the future. Our paper creates opportunities for other countries for comparison, and also for adapting best practices, especially within the European Union.

\section{Traditional historical documents: a research model for discovering roots}

Processing the entirety of the printed Hungarian literature on shipping from the very beginning is a task yet to be accomplished. For this reason, in the first part of our paper we outline a complex, long-term research model, which is based on a specific piece of research and consists of several stages regarding both the collections and the time periods to be involved. This method enables the professional processing of traditional historical documents in order to satisfy the needs of the field in a way that is competitive even by international standards ${ }^{1}$.

There is no extensive summary of the scientific literature on shipping in Hungary. Works published after the change of the political system either deal with specific topics, e.g. the history or the ethnographic aspects of shipping, famous persons, the interpretation of certain concepts, or regional development; or they were written for educational purposes. Besides schoolbooks, the most recent publications are the voluminous monography titled The History of Danube-seafaring in Hungary ${ }^{2}$, and the Hungarian adaptation of the Austrian Via Donau volume, the Manual on Danube Navigation ${ }^{3}$. Several memoirs were published as well, which are valuable pieces of contemporary history. But the circulation of printed or electronic works compiled of presentations given at conferences is not widespread.

In the Institute of Library and Information Science of the Faculty of Humanities of Eötvös Loránd University, in line with the European Union Strategy for the Danube

P. Kiszl, A magyar nyelvü hajózási szakirodalom rekonstrukciója az Európai Unió Duna Régió Stratégiájának tükrében, Közlekedéstudományi Szemle, vol. 68: 2018, no. 3, pp. 46-53, https://doi.org/10.24228/KTSZ.2018.3.5.

2 A magyar Duna-tengerhajózás története, ed. G. Hadnagy, Budapest 2017.

3 A dunai hajózás kézikönyve, ed. R. Rafael, Á. Bálint, T. Jármy, Budapest 2013 [online], [available 28 V 2019]. Available on the World Wide Web: http://dhk.rsoe.hu. 
$\operatorname{Region}^{4}$, and strengthening its cultural action plan, we made it our mission to prepare an annotated bibliography of shipping after analysing the most prominent public collections of Hungary. This would be followed by discovering the interconnections in the history of shipping, identifying book collections of each given period where possible, etc. We start with the collection of the University Library and Archives of Eötvös Loránd University, which has been consistently expanded since 1561, and was the first (1780) to have rights for legal deposits. Afterwards we move on to the collections of the National Széchényi Library, the National Technical Information Center and Library of Budapest University of Technology and Economics, and The Hungarian Museum of Science, Technology, and Transport. Unfolding the history of the no longer existing library of the Hungarian Shipping Company (Magyar Hajózási Részvénytársaság - MAHART) is an individual project. As far as transport information service in Hungary is concerned, shipping has little importance, especially in relation to its economic weight. The majority of new publications are educational or historic in nature, with only a few scattered examples of works with a scientific approach. This has not always been the case. Which is one of the reasons why we feel obligated to introduce our library roots systematically, while recalling the heyday of professional shipping.

\section{Research background}

We have already examined the Hungarian scientific literature on shipping available online during our previous research in the Institute of Library and Information Science of Eötvös Loránd University 5 . A major result of our examinations - besides the expansion of the literature of the field, which has been sadly underrepresented for decades - is the organization, categorization and analysis of existing document sources pursuant to current information service principles. At the same time, it is our declared intention to disseminate scientific knowledge of shipping to the public.

Our book published in 2010, Hálózati révkalauz (Network pilot), contrary to its title, does not only deal with online content. It has valuable historic content, e.g. it recounts the foundation of the Danube Commission and introduces the chronology of the Hungarian Shipping Company, accompanied by a unique, graphically depicted family tree of the late ventures of this state-owned enterprise. Furthermore, it also provides comprehensible definitions for technical terms necessary to understand the topic (e.g. water levels, notices for boatmen) and explanations for contemporary issues of waterborne transport (e.g. navigability of the Danube, trainings). Moreover, the book contains evaluations of public collections with various carriers (e.g. Hungarian Digital Image Library, The National Archives of Hungary,

4 EU Strategy for the Danube Region, [in:] European Commission website [online], [available 28 V 2019]. Available on the World Wide Web: https://ec.europa.eu/regional_policy/en/policy/cooperation/macro-regional-strategies/ danube; Danube Region Strategy [online], [available 28 V 2019]. Available on the World Wide Web: https://www. danube-region.eu.

5 P. Kiszl, Navigare necesse est... Magyarországi hajózási információforrások az interneten, Tudományos és Műszaki Tájékoztatás, vol. 55: 2008, no. 5, pp. 207-220; idem, Hálózati révkalauz. Magyarországi hajózási információforrások az interneten, Eger 2010. 
National Audiovisual Archive) and statistics yet unpublished (e.g. register data from the former National Transport Authority).

After systematically listing all information sources available online, a new, clearly definable research topic emerges: the deeper, scientific processing of traditional (printed) documents related to shipping (and relevant documents related to water management, environmental protection, etc.) which are valuable as cultural heritage. This could be a helpful effort from Hungary to assist the EU's cultural endeavours aimed at developing the Danube Region, and to help the domestic implementation of the Danube Region Strategy ${ }^{6}$.

Since shipping in Hungary is mostly concentrated on the Danube, we have reviewed the related publications of the Danube Commission ${ }^{7}$, the only interstate organization with its seat in Budapest since 1954 with a library expanding since 1856, since the Treaty of Paris ending the Crimean War also founded the European Danube Commission. But due to the nature and the mission of the organization there is little background material available for our planned research. German, Russian, and French publications are mostly its own compilations related to nautical, hydrological, statistical, and other topics. Our searches related to Hungary performed in the biggest national libraries (The British Library, Bibliothèque Nationale de France, Library of Congress) have not yielded surprising results either. Most of the matches are fiction, almanacs, memoirs, publications on military history, maps, and other navigational documents.

It is important to note the last of the seven points of debate (Danube Program) outlined by the Hungarian Academy of Sciences in 1997 to develop future research plans: the new synthesis of scientific fields. "The seventh aim of the Danube cooperation is to create a new kind of professional forum for academics"8, writes the then president of the Academy, Ferenc Glatz. Our call for action is very similar: to create an interdisciplinary forum and a cooperative community for ventures aimed at discovering the scientific literature on shipping.

\section{The key objective of the research}

We have limited knowledge of the number, bibliographic data, content, authors, etc. of the earliest Hungarian publications related to shipping. Institutions in the field of transport science often operate in isolation or with very little cooperation, and have not yet reached the phase of digitizing these scientific documents and publishing them online ${ }^{9}$. Therefore, our planned research focuses on the following:

1) The bibliographic registration of Hungarian scientific literature on shipping.

2) Assessing the content of the collected documents.

\footnotetext{
6 [Nyitóoldal], [in:] Duna Régió Stratégia [online], [available 28 V 2019]. Available on the World Wide Web: http:// dunaregiostrategia.kormany.hu.

7 Catalogue of Publications of the Danube Commision as of 1 January 2019 [online], [available 28 V 2019]. Available on the World Wide Web: http://www.danubecommission.org/uploads/doc/Catalogue_2019/Catalogue_en_2019.pdf.

8 F. Glatz, Hét pont a Dunáról, Ezredforduló, vol. 1: 1997, no. 1, p. 28.

9 Trendek, [in:] Közlekedéstudományi Intézet [online], [available 28 V 2019]. Available on the World Wide Web: http:// www.kormany.hu/download/9/ac/11000/K\%C3\%B6zgy\%C5\%B1jtem\%C3\%A9nyi\%20Digitalizl\%C3\%A1si\%20 Strat\%C3\%A9gia_2017-2025.pdf.
} 
3) Following up on the authors' works.

4) Identifying significant book collections based on owners' marks, bookplates, and bookplate stamps.

5) Discovering connections and outlining shipping issues of each given period.

6) Projecting the effect of the tasks listed above onto our current circumstances within the context of the Danube Region Strategy in order to strengthen cultural identity, since "the local communities of the Danube Region find their place on the map of Europe by organizing themselves based on their values and culture"10.

\section{Libraries and collections to be involved in the research}

As a first step, we plan on starting the collection from the very beginning until 1949 in the collection of the University Library and Archives of Eötvös Loránd University (II. 1). We chose this specific collection because:

1) our research opportunities are favourable due to our institutional background;

2) until the leftist tilt the library had an encyclopaedic field of collection;

3) its collection founded in 1561 is unique both at a national and at a European level;

4) due to the lack of bibliographic descriptions and contextual analyses, tracking the documents proves to be a real challenge for library professionals.

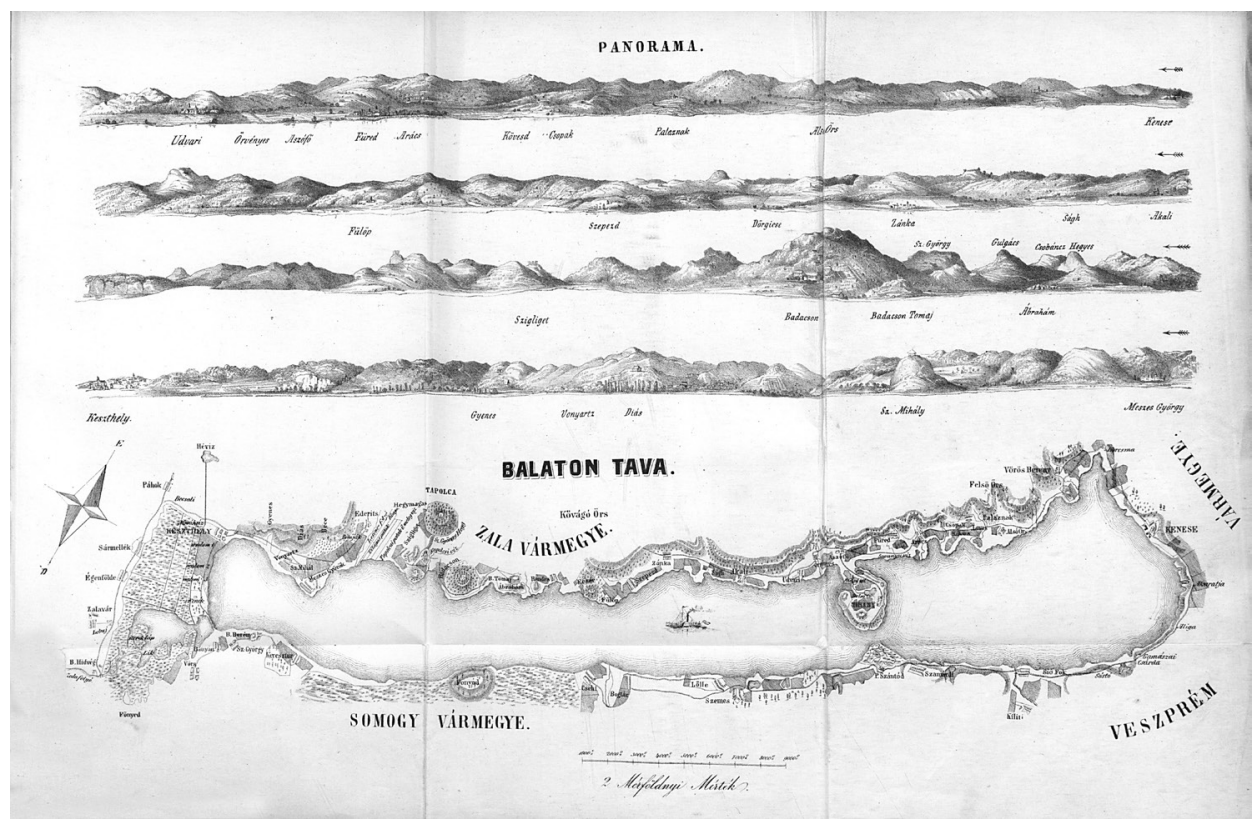

III.1. Balaton Album (1848)

Source: University Library and Archives of Eötvös Loránd University. Excerpt. Hd 5482.

10 Duna Programiroda, Budapest 2010, p. 16. 
National Széchényi Library, the national library of Hungary may prove to be an essential pillar by providing services and cohesive power over the domestic book culture with its collection of nearly four million books. Some of the works published before 1986 are only available through the locally usable card index, and cannot be browsed online. Besides the books stored at the Buda Castle its rich collection of periodicals (of nearly 400,000 volumes) includes a few journals known even to the boatmen of today, such as:

- all (40) volumes of Hungarian Shipping (Magyar Hajózás), the former official journal of the Hungarian Shipping Company, published from 1963 until 2003. (There were periodicals published under the same name before: Hungarian Shipping, 1898-1918 and Hungarian Shipping. Shipping and Port Journal, 1947-1948, Shipping Department of the Ministry of Transport.);

- Water Transport (Víziközlekedés), with 19 volumes published between 1972 and 1990, a publication of the Hungarian Shipping Company;

- Information on Shipping Literature (Hajózási Szakirodalmi Tájékoztató), a journal of abstracts published by the Hungarian Shipping Company and the National Technical Information Center and Library between 1983 and 1995.

Naturally, there are many other titles included (e.g. Shipping Gazette - Hajózási Hírlap, 1928-1944). With this short list we wished to illustrate that the preparation and/or digitization of journal articles is another task to be taken on.

The National Technical Information Center and Library of Budapest University of Technology and Economics was created by merging the two libraries included in its name in 2001, therefore its technical field of collection also includes certain topics related to shipping. Owing to the professional support of the Department of Aeronautics, Naval Architecture and Railway Vehicles of Budapest University of Technology and Economics, and the topic monitoring services of the National Technical Information Center and Library mentioned above, we can expect to find many matches.

Among higher education institutions we need to mention the University Library of Széchenyi István University in Györ. According to a study published in 1996 on the collection of The Hungarian Museum of Science, Technology and Transport, $9 \%$ of their books and $8 \%$ of their journals deal with the topic of waterborne transport. ${ }^{11}$ These numbers are likely lower now, but further examination is essential. We also wish to examine the catalogues of the Library and Information Center of the Hungarian Academy of Sciences, the Library of the Hungarian Parliament, further technical libraries, and the Metropolitan Ervin Szabó Library, especially its Budapest Collection. If possible, we would like to involve private collections in our research as well.

We cannot avoid the different technical databases either, e.g. the Arcanum Digitheca, ${ }^{12}$ which is constantly expanding its collection of scanned periodicals, and

\footnotetext{
11 J. Barkóczi, I. Tisza, A Közlekedési Múzeum tudományos szakkönyvtára, [in:] A Közlekedési Múzeum Évkönyve, ed. A. Katona, Budapest 1996, vol. 10, pp. 223-235.

12 Arcanum Digitheca [online], [available 28 V 2019]. Available on the World Wide Web: https://www.arcanum.hu/en.
} 
the Hungaricana ${ }^{13}$. Another example is the ever-expanding online content of the National Library, partially owing to the developments of the National Library System (Országos Könyvtári Rendszer - OKR). ${ }^{14}$ Besides the Arcanum, the control of the mostly international literature available through the Electronic Information Service National Programme (Elektronikus Információszolgáltatás Nemzeti Program) ${ }^{15}$ is also justified.

Presenting the history of the Hungarian Shipping Company's Library is a separate task in itself. We have very limited knowledge of its collection. One thing is certain: 3,142 documents of the specialized library was handed over to the Hungarian Secondary Vocational School of Shipping on 28 November 2003, without a list containing the details ${ }^{16}$. We have no information on the majority of the document collection; it never ended up at the Hungarian Technical and Transportation Museum ${ }^{17}$. We quote the statement given by the librarian teacher of the Hungarian Secondary Vocational School of Shipping: "I was informed by older boatmen that the biggest part of the materials, consisting of unknown documents, was stored in a storage unit in Újpest, where it got destroyed by the next flood"18.

\section{Professional cooperation}

University students and doctoral students take part in our professional programme as well, mostly during the collection of materials. The opportunity to further examine the topic and the collected material within the framework of specialized courses presents itself as well. It is unavoidable to involve professionals from the fields of literary history, library science, engineering, shipping, history, etc.; and professional organizations (the Shipping Section of the Association of Transport Sciences, the National Shipping Federation of Hungary, the Association for Hungarian Shipping, the Hungarian Seamen's Association) in our project.

The exploration of Hungarian scientific literature on shipping appears among the topics of the Library Science Doctoral Programme of the Doctoral School of Literary Studies of Eötvös Loránd University: "Supporting - mostly the cultural action plans, the intellectual heritage protection efforts, and the regional organization effects of - the macroregional EU Danube Strategy through the widespread publication of the historical roots of Hungarian shipping. This includes bibliographic and contextual analysis, preparing an annotated bibliography, identifying collections based on owner's notes, and identifying further connections"19.

\footnotetext{
${ }_{13}$ [Home], [in:] Hungaricana, Hungarian Cultural Heritage Portal [online], [available 28 V 2019]. Available on the World Wide Web: https://hungaricana.hu/en.

14 P. Kiszl, R. Radó, M. P. Hubay, From Divergence to Convergence in Hungarian Librarianship: Towards a Common Digital Platform, Libri, vol. 68: 2018, no. 4, pp. 315-329, https://doi.org/10.1515/libri-2018-0049.

15 [Home], [in:] Electronic Information Service National Programme [online], [available $28 \mathrm{~V} 2019$ ]. Available on the World Wide Web: http://www.eisz.mtak.hu/index.php/en.

${ }_{16}$ Átadás-átvételi jegyzőkönyv a MAHART szakkönyvtár állományának átadásáról, 28.11.2003, MAHART, Budapest, Hungary.

17 B. Benei, e-mail to the author, February 15, 2018.

18 Cs. Keresztessy, e-mail to the author, February 16, 2018.

19 P. Kiszl, A magyarországi hajózási szakirodalom rekonstrukciója, [in:] Országos Doktori Tanács Témakiírás (Hungarian Doctoral Council. Thesis topic proposal) [online], [available 28 V 2019]. Available on the World Wide Web: https:// doktori.hu/index.php?menuid=195\&tk_ID=142060\&lang=EN.
} 


\section{Project schedule}

Our resource-focused research project defines long-term (longer than 5 years) tasks. The intensity of the planned works depends on the available financial (e.g. tendering) opportunities and the cooperating partners:

1) Collecting materials;

2) Compiling the annotated bibliography;

3) Analysing the content of the documents;

4) Researching the authors' biographical data;

5) Analysing indications of ownership, bookplates, and owner's marks;

6) Disseminating interim results;

7) Identifying connections;

8) Disseminating results;

9) Compiling a monography based on theoretical and empirical results, and publishing and maintaining an online content providing platform.

We are considering different time frames. We have mentioned the year 1949 in connection with the University Library and Archives of Eötvös Loránd University, but regarding the scope of the whole research the change of the political system as an expanded horizon might come into play. This will be determined by the available capacity.

\section{Expected results}

We expect our project to gain both domestic and international attention across disciplines. Besides the scientific community of history and literary studies, we aim to satisfy the needs of the shipping profession and the library information service. Furthermore, through discovering and processing documents and information sources on shipping, and even through the service thereof via a repository platform, the project might forge a close-knit community among those interested in Hungarian shipping.

\section{Online information systems now}

Modern infocommunicational tools open new perspectives for both academic-professional and educational information service, since the two often merge nowadays, which puts a tremendous amount of responsibility on the shoulders of librarians ${ }^{20}$. We do not exclude the most common, free online resources either: public information service happens on the same platforms whether it comes to shipping or everyday topics.

\footnotetext{
${ }_{20}$ P. Kiszl, J. Fodor, The "Collage Effect" - Against Filter Bubbles: Interdisciplinary Approaches to Combating the Pitfalls of Information Technology, Journal of Academic Librarianship, vol. 44: 2018, no. 6, pp. 753-761. https://doi. org/10.1016/j.acalib.2018.09.020.
} 


\section{Geography}

The oldest and probably most commonly used resources are related to weather and its monitoring. In Hungary the recording of water levels goes back to 1823, and after almost a decade-long break they still broadcast the current levels on Kossuth Radio after the 2 p.m. news every day. The data comes from the National Hydroinformation Service of the General Directorate of Water Management of the Ministry of Interior. The organisation has a website called Hydroinfo ${ }^{21}$ with maps, graphs, and tables on the following data related to the Danube, the Tisza and their tributaries:

- hydrological information,

- hydrological forecasts,

- meteorological information,

- meteorological forecasts,

- snow conditions,

- ice conditions,

- notices,

- information on shipping,

- glossary.

Its archives contain the Central Hydrological Database (II. 2), yearly water level tables, and daily flow regime maps.

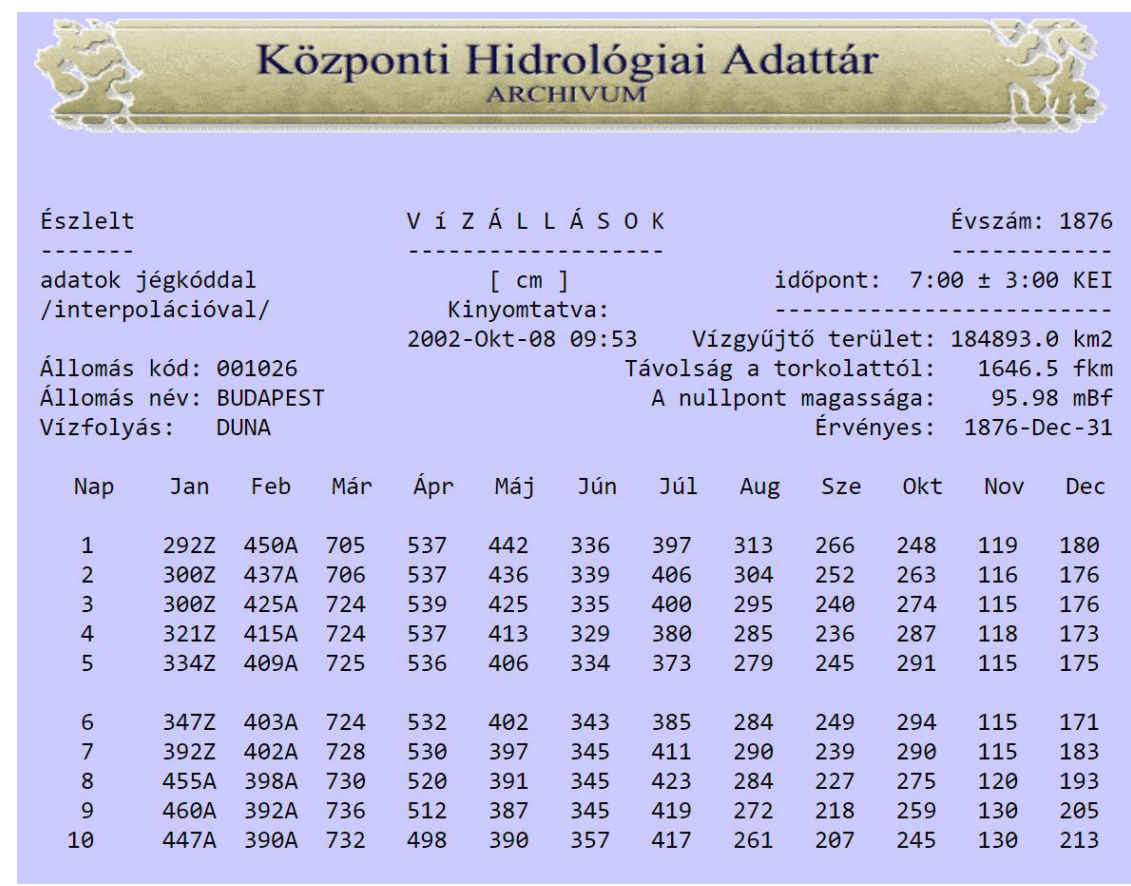

III. 2. Archive of the Central Hydrological Database. Water levels of the Danube at Budapest in 1876. Excerpt.

Source: http://www.hydroinfo.hu/vituki/archivum/bp1876.htm

${ }_{21}$ [Home], [in:] Hungarian Hydrological Forecasting Service [online], [available 28 V 2019]. Available on the World Wide Web: http://www.hydroinfo.hu/en. 
The Water Management Website 22 operated by the General Directorate of Water Management provides complex information service. Operative water levels and flood control alert levels are searchable in map format. One of its popular services is the map collection of the Geomatic Website of Water Management, which contains, among others:

- the probability of floods (3D application),

- water-related memorials and events,

- a map for water tours.

The National Directorate General for Disaster Management of the Ministry of Interior in collaboration with the National Association of Radio Distress-Signaling and Infocommunications provides storm forecasts and storm warning for the lakes of Hungary (Lake Balaton, Lake Velence, Lake Tisza, and Lake Fertő). This service, named Viharjelzés Online ${ }^{23}$ (Storm Warning Online) from 1 April until 31 October each year, and all the information is available online.

Webcams are useful tools that offer information as well, and their number is increasing in Hungary. On the website called Időkép ${ }^{24}$ (Weather Image) there are 525 webcams available, many of which are placed near rivers and lakes.

\section{Transport}

In Hungary real-time information on the positions of ships is easily accessible for free and without registration through e.g. the system of Marinetraffic ${ }^{25}$ (II. 3). Similar services are the Shipfinder ${ }^{26}$ and the Vessel Finder ${ }^{27}$. Since ships move across borders, there would be no point in developing national systems. All of the above are international, map-based tools, which make it possible to track the movements of vessels all over the world.

Scheduled passenger vessels operate only in the capital, Budapest. Passengers are assisted by the interactive schedule service ${ }^{28}$ called BKK Futár (BKK Courier). The map-based search engine of ferries and ports was developed by Útinform ${ }^{29}$ (Traffic info). The company Mahart Passnave Kft., which owns 38 ports nationwide, publishes the arrival and departure time of passenger vessels going through Budapest on its website ${ }^{30}$.

\footnotetext{
22 Vízügyi Honlap, [in:] Országos Vízügyi Föigazgatóság [online], [available 28 V 2019]. Available on the World Wide Web: https://www.vizugy.hu.

23 Viharjelzés Online, [in:] Rádiós Segélyhívó és Infokommunikációs Országos Egyesület [online], [available 28 V 2019]. Available on the World Wide Web: http://www.rsoe.hu/tevekenysegek/viharjelzo.

${ }_{24}$ Kamerák, [in:] Időkép [online], [available 28 V 2019]. Available on the World Wide Web: https://www.idokep.hu/ webkamera.

25 MarineTraffic, [in:] MarineTraffic [online], [available 28 V 2019]. Available on the World Wide Web:

https://www.marinetraffic.com/en.

${ }_{26}$ Shipfinder, [in:] Shipfinder [online], [available 28 V 2019]. Available on the World Wide Web: https://www.shipfinder. com.

27 Vessel Finder, [in:] Vessel Finder [online], [available 28 V 2019]. Available on the World Wide Web: https://www.vesselfinder.com.

${ }_{28}$ BKK Futár, [in:] BKK Budapesti Közlekedési Központ [online], [available 28 V 2019]. Available on the World Wide Web: http://futar.bkk.hu.

29 Útinform Kompok, [in:] Magyar Közút Nonprofit Zrt. [online], [available 28 V 2019]. Available on the World Wide Web: https://www.utinform.hu/kompok.

30 Mahart Ports, [in:] MAHART Passnave Ltd. [online], [available 28 V 2019]. Available on the World Wide Web: https:// www.mahartports.hu/en.
} 


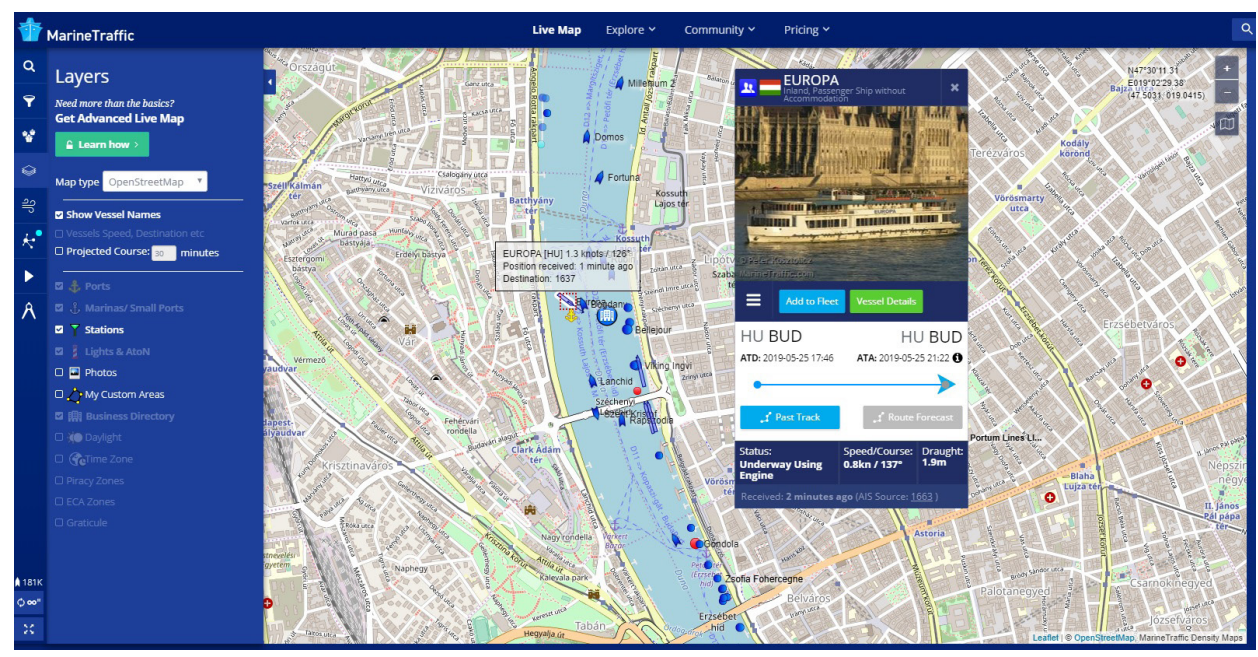

III. 3. MarineTraffic. Real-time map fragment of the Danube at Budapest with the data sheet of the passenger vessel Európa

Source: https://www.marinetraffic.com/en/ais/home/centerx:19.046/centery:47.501/zoom:15

\section{Authorities}

After introducing water management websites, we need to mention content published by shipping authorities. Due to a recent reorganization, the related authority functions are performed jointly by the Department for Shipping Authority of the Ministry for Innovation and Technology and the Department of Transport of the Government Office of Budapest. The online platform has not been redesigned yet; all notices and information for boatmen, topics and questions for shipping examinations, various registries, the register of ship's doctors, and all forms required for administration are available at the old websites ${ }^{31}$.

The contact information for the water police stations are available at the website of the Hungarian Police ${ }^{32}$. The Transportation Safety Bureau ${ }^{33}$ of the Ministry for Innovation and Technology provides news about waterborne traffic accidents and publishes the results of its examinations in table format.

\section{Community initiatives}

There are enormous amounts of information on Hungarian shipping available at the websites of the most prominent non-governmental organizations. The exem-

\footnotetext{
31 Shipping Authority, [in:] National Transport Authority Central Office [online], [available 28 V 2019]. Available on the World Wide Web: http://www.nkh.gov.hu/en/web/english/shipping.

32 [Home], [in:] Hungarian National Police Headquarters [online], [available $28 \mathrm{~V}$ 2019]. Available on the World Wide Web: http://www.police.hu/en.

${ }^{33}$ Navigation, [in:] Transportation Safety Bureau of Hungary [online], [available $28 \mathrm{~V}$ 2019]. Available on the World Wide Web: http://www.kbsz.hu/j25/en/navigation.
} 
plary database called Hajóregiszter ${ }^{34}$ (Vessel register; II. 4) should be highlighted, which was created at the initiative of the Association for Hungarian Shipping, and is expanding through community cooperation to this day. The database aims to folia toru niensia virtually collect and make searchable all vessels flying the Hungarian flag on lakes, rivers, and seas. Search criteria are:

- name of vessel,

- inland waterway company,

- maritime company,

- shipyard,

- catalogue (vessel type),

- source.

Entries on each vessel data sheet, usually accompanied by several images are:

- technical data,

- vessel history,

- known owners,

- sources.

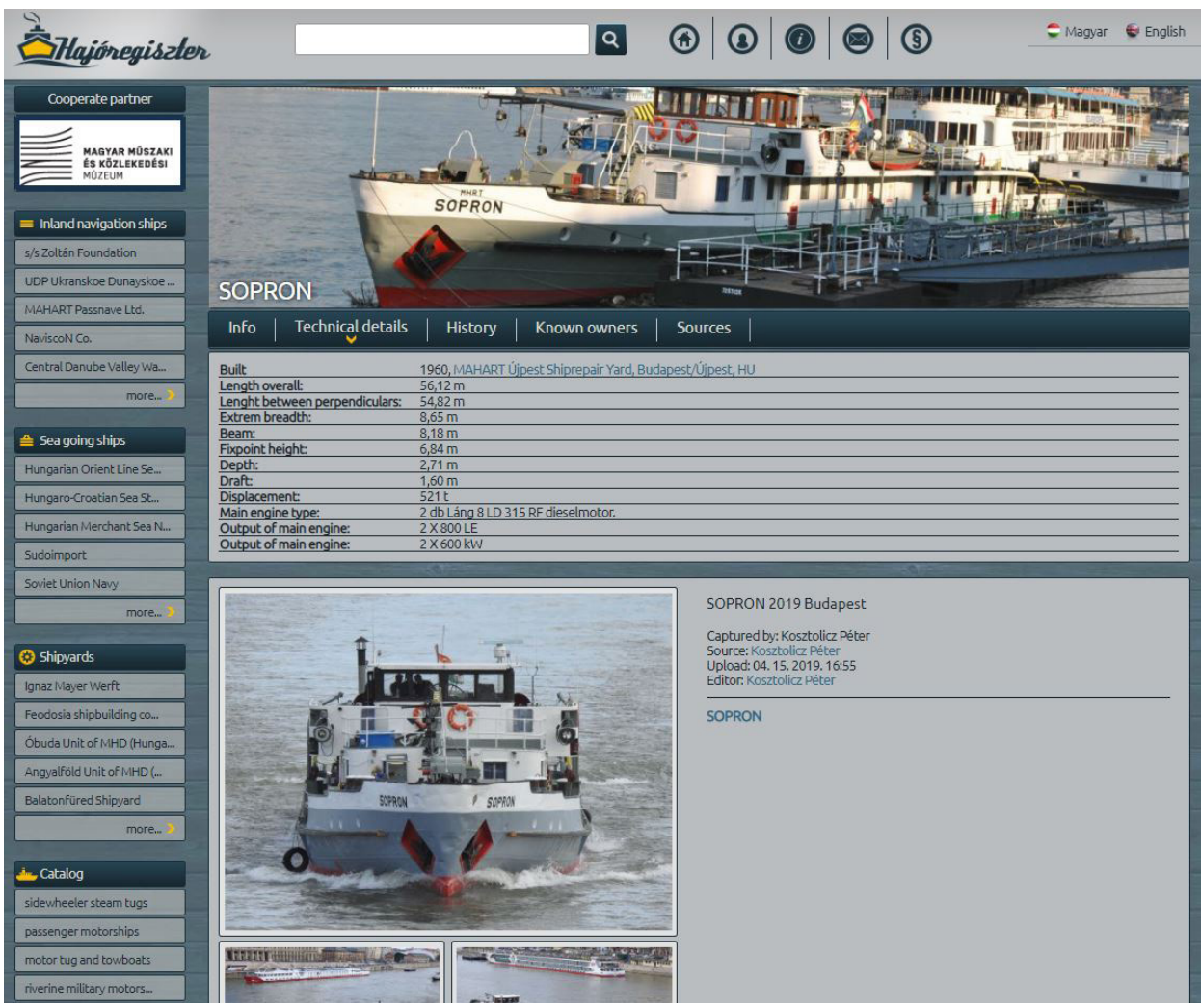

III. 4. Hajóregiszter. Data sheet of the tugboat Sopron

Source: http://www.hajoregiszter.hu/hajoadatlap/sopron/335

${ }^{34}$ [Nyitóoldal], [in:] Hajóregiszter [online], [available 28 V 2019]. Available on the World Wide Web: http://www. hajoregiszter.hu. 


\section{Document collections}

The electronic library of the aforementioned Danube Commission ${ }^{35}$ contains documents dating back to 2003 in German, French, and Russian. Its library and archives can be researched on site. The Danube Commission publishes the updated catalogue of its publications every year.

We have already mentioned the Manual on Danube Navigation published in 2002 by the Via Donau, which is a widely used information aid, but is in need of an update.

The service called Trendek (Trends) of the Institute for Transport Sciences ${ }^{36}$ publishes graphic compilations, using mostly the data from the Hungarian Central Statistical Office. It provides data on the performance of inland freight water transport, and it publishes prognoses on transport sectors based on EU sources. The Institute's public library of transport science has more than 40,000 volumes. Its collection includes Hungarian and foreign language books, research reports, so-called grey literature and journals, while there are also databases to assist the theoretical and practical professionals of transport.

\section{Integration: the way forward}

In the case of information sources on shipping as well, developments are aimed at the integration of services. The content services introduced above, which are mostly independent and isolated from each other, often end up creating duplications. A close cooperation would be necessary. Our vision is that linked, often multimedia-based content, which is often paired with three dimensional (3D), or even Virtual Reality (VR) or Augmented Reality (AR) tools, be complemented by free social applications (e.g. uploading photos) and collaborational techniques. Applications transmitting real-time content (e.g. schedules, locations) and providing prognoses on mobile devices is becoming a basic service.

This requires considerable resources. The appropriate operation of international, English databases available on one single platform can only be realized with the help of projects supported by EU tenders. We hope that several priority areas of the European Union Strategy for the Danube Region (EUSDR) are linked to the innovations of library and information science:

- Priority Area 3: Culture \& Tourism

- Priority Area 7: Knowledge Society

- Priority Area 9: People \& Skills

Similarly, the priority areas of the Interreg's Danube Transnational Programme (DTP), supported by the EU, will be relevant in library information service:

- Innovative and socially responsible Danube region

- Environment and culture responsible Danube region

35 E-library, [in:] Danube Commission [online], [available 28 V 2019]. Available on the World Wide Web: http://www. danubecommission.org/dc/en/publishing-activities/e-library.

36 Trendek, [in:] Közlekedéstudományi Intézet [online], [available 28 V 2019]. Available on the World Wide Web: http:// www.kti.hu/trend-kti. 
- Better connected and energy responsible Danube region

- Well-governed Danube region
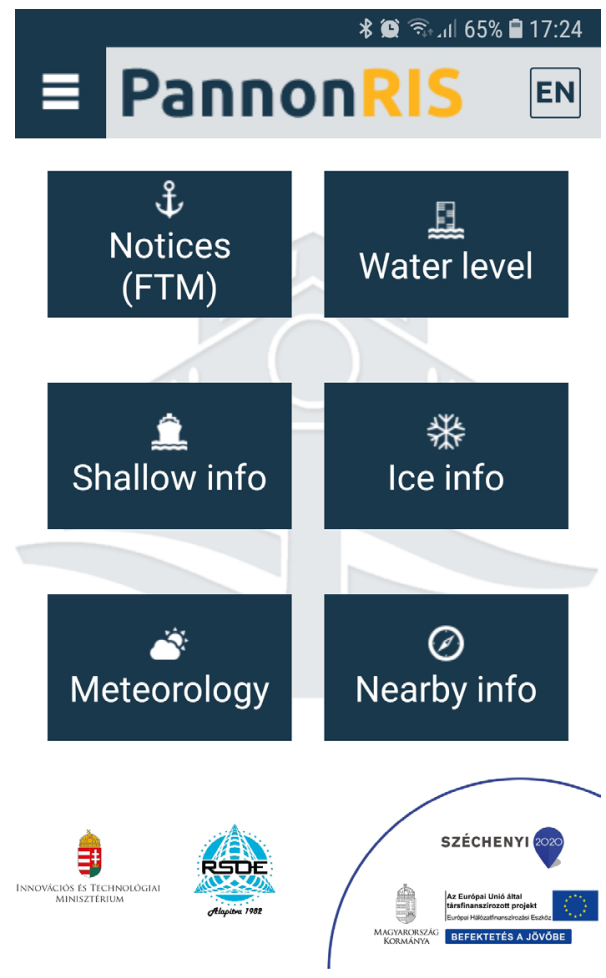

III. 5. Home page of the PannonRIS mobile application

Source: PannonRIS mobile application

The Hungarian PannonRIS, which is currently still being developed with the support of Interreg, is a good example of the integration of information services related to shipping. It provides valuable data for free through its mobile application: water level data on the Hungarian section of the Danube, notices for boatmen, ford and ice conditions, meteorological forecasts, and current map information based on location (II. 5). After logging in, professional services for boatmen (e.g. traffic information, compensation support, customs) are available as well. This service containing archives and providing graphic displays (e.g. diagrams) serves two target groups: the laymen, who use the application for recreational purposes; and the professional audience. We would like to reiterate that parallel content development is unnecessary due to infocommunicational innovations. The road to differentiating between satisfying user groups and specific interests is already set, which will soon be further assisted by artificial intelligence solutions. 


\section{Summary}

Due to the development of information technology, the networking of massive amounts of data from different sources and stored in different formats may lead to the discovery of new, yet undiscovered connections. In many cases this may supplement, refine, or even change our scientific view of past ages; let us think about the results of digital humanities. ${ }^{37}$ The simple publication of documents (not only texts, but also audio files, etc.) and physical artefacts (tools, buildings) through visual representation is usually not enough anymore. Our time requires multi-aspect, automated processing, and the display of connections accompanied by modern visualization tools by utilizing IT innovations based on multidisciplinarity. As the thematic websites on shipping listed in this paper prove, programmes are best realized in international cooperation and (financial) support, based on the standards of data exchange of public collections and libraries. The target audience should not be limited to the professionals of history, shipping, etc., or those of public collections and developers. Introduced through the topic of information service on shipping, we discussed resource networks that are multi-functional, scientific, but still easy to use, often visually impressive, and eye-catching, but cannot be considered reference services in the traditional sense of the word, since laymen are expected to use them as well. We may witness a new evolutional step in the development of information service tools.

\section{Bibliography}

Arcanum Database Ltd. n.d. „Arcanum Digitheca”. Accesses May 28, 2019. https://www.arcanum.hu/en.

Átadás-átvételi jegyzőkönyv a MAHART szakkönyvtár állományának átadásáról. 28.11.2003. MAHART, Budapest, Hungary.

Barkóczi, Jolán and István Tisza. 1996. "A Közlekedési Múzeum tudományos szakkönyvtára”. In A Közlekedési Múzeum Évkönyve, ed. András Katona, 10: 223235. Budapest: Közlekedési Múzeum.

Bernadett Benei, e-mail to the author, February 15, 2018.

BKK Budapesti Közlekedési Központ. n.d. „BKK Futár”. Accesses May 28, 2019. http://futar.bkk.hu.

Csaba Keresztessy, e-mail to the author, February 16, 2018.

Danube Commission. 2019. Catalogue of Publications of the Danube Commision as of 1 January 2019. Budapest. Accesses May 28, 2019. http://www. danubecommission.org/uploads/doc/Catalogue_2019/Catalogue_en_2019.pdf.

Danube Commission. n.d. „E-library”. Accesses May 28, 2019. http://www. danubecommission.org/dc/en/publishing-activities/e-library.

Danube Region Strategy. n.d. „[Home]”. Accesses May 28, 2019. https:// www.danube-region.eu.

Duna kézikönyv. 2010. Duna Programiroda. Budapest: Studio Metropolitana.

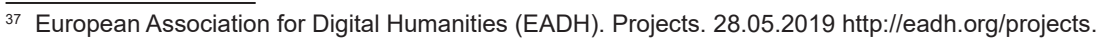


Duna Régió Stratégia. 2017. „[Nyitóoldal]”. Accesses May 28, 2019. http:// dunaregiostrategia.kormany.hu.

Electronic Information Service National Programme. n.d. "[Home]". Accesses May 28, 2019. http://www.eisz.mtak.hu/index.php/en.

European Association for Digital Humanities (EADH). n.d. "Projects". Accesses May 28, 2019. http://eadh.org/projects.

European Commission website. 2011. „EU Strategy for the Danube Region”. Accesses May 28, 2019. https://ec.europa.eu/regional_policy/en/policy/cooperation/ macro-regional-strategies/danube.

Glatz, Ferenc. 1997. "Hét pont a Dunáról”. Ezredforduló 1(1): 25-28.

Hadnagy, Gábor ed. 2017. A magyar Duna-tengerhajózás története. Budapest: Magyar Tengerészek Egyesülete.

Hajóregiszter. n.d. „[Nyitóoldal]”. Accesses May 28, 2019. http://www.hajoregiszter.hu.

Hungarian Hydrological Forecasting Service. n.d. "[Home]". Accesses May 28, 2019. http://www.hydroinfo.hu/en.

Hungarian National Police Headquarters. n.d. „[Home]”. Accesses May 28, 2019. http://www.police.hu/en.

Hungaricana, Hungarian Cultural Heritage Portal. n.d. "[Home]". Accesses May 28, 2019. https://hungaricana.hu/en.

Időkép Kft. n.d. „Kamerák”. Időkép. Accesses May 28, 2019. https://www. idokep.hu/webkamera.

Kiszl Péter. 2018. „A magyarországi hajózási szakirodalom rekonstrukciója”. Országos Doktori Tanács Témakiírás (Hungarian Doctoral Council. Thesis topic proposal). Accesses May 28, 2019. https://doktori.hu/index.php?menuid=195\&tk $I D=142060$ \&lang $=E N$.

Kiszl, Péter and Fodor, János. 2018. "The "Collage Effect" - Against Filter Bubbles: Interdisciplinary Approaches to Combating the Pitfalls of Information Technology". Journal of Academic Librarianship. 44(6): 753-761. https://doi.org/10.1016/j.acalib.2018.09.020

Kiszl, Péter, Rita Radó, and Péter Miklós Hubay. 2018. "From Divergence to Convergence in Hungarian Librarianship: Towards a Common Digital Platform". Libri. 68(4) 315-329. https://doi.org/10.1515/libri-2018-0049

Kiszl, Péter. 2008. „Navigare necesse est... Magyarországi hajózási információforrások az interneten." Tudományos és Müszaki Tájékoztatás 55(5): 207-220.

Kiszl, Péter. 2010. Hálózati révkalauz. Magyarországi hajózási információforrások az interneten. Eger: EKF Líceum Kiadó.

Kiszl, Péter. 2018. "A magyar nyelvű hajózási szakirodalom rekonstrukciója az Európai Unió Duna Régió Stratégiájának tükrében”. Közlekedéstudományi Szemle. 68(3): 46-53. https://doi.org/10.24228/KTSZ.2018.3.5.

Közlekedéstudományi Intézet. n.d. „Trendek”. Accessed May 28, 2019. http:// www.kti.hu/trend-kti.

Magyar Közút Nonprofit Zrt. n.d. „Útinform Kompok“. Accesses May 28, 2019. https://www.utinform.hu/kompok. 
MAHART Passnave Ltd. n. d. "Mahart Ports". Accessed May 28, 2019. https:// www.mahartports.hu/en.

MarineTraffic. n.d. "MarineTraffic". Accessed May 28, 2019. https://www. marinetraffic.com/en.

National Transport Authority Central Office. n.d. „Shipping Authority”. Accesses May 28, 2019. http://www.nkh.gov.hu/en/web/english/shipping.

NN. n.d. "Közgyüjteményi Digitalizálási Stratégia 2017-2025". Accessed May 28, 2019. http://www.kormany.hu/download/9/ac/11000/K\%C3\%B6zgy\%C5\%B1jtem\%C3\%A9nyi\%20Digitalizl\%C3\%A1si\%20Strat\%C3\%A9gia_2017-2025.pdf.

Országos Vízügyi Föigazgatóság. n.d. „Vízügyi Honlap”. Accesses May 28, 2019. https://www.vizugy.hu.

Rádiós Segélyhívó és Infokommunikációs Országos Egyesület. n.d. „Viharjelzés Online“. Accesses May 28, 2019. http://www.rsoe.hu/tevekenysegek/viharjelzo.

Rafael, Róbert, Ágnes Bálint, and Tibor Jármy, ed. 2013. "A dunai hajózás kézikönyve. Budapest". Rádiós Segélyhívó és Infokommunikációs Országos Egyesület. Accesses May 28, 2019. http://dhk.rsoe.hu/download/dhk.pdf.

Shipfinder. n.d. "Shipfinder". Accesses May 28, 2019. https://www.shipfinder. com.

Transportation Safety Bureau of Hungary. n.d. "Navigation". Accesses May 28, 2019. http://www.kbsz.hu/j25/en/navigation.

Vessel Finder. n.d. „Vessel Finder“. Accesses May 28, 2019. https://www. vesselfinder.com.

Received: 23 VI 2019

Accepted: 23 VIII 2019 


\section{Péter Kiszl}

Uniwersytet Eötvösa Loránda w Budapeszcie, Wegry. Wydział Humanistyczny e-mail: kiszl.peter@btk.elte.hu

ORCID ID: 0000-0003-2992-295X

Dr. Hab. Péter, Kiszl, bibliotekarz i ekonomista, profesor nadzwyczajny na Uniwersytecie Eötvösa Loránda w Budapeszcie (Węgry). Jest dyrektorem Instytutu Bibliotekoznawstwa i Informacji Naukowej (LIS), kierownikiem Zakładu Informacji Naukowej, dyrektorem programu doktoranckiego LIS, kierownikiem studiów licencjackich i magisterskich LIS, dyrektorem Centrum Humanistyki Cyfrowej, przewodniczącym Rada Nadzorcza Fundacji Biblioteki Uniwersyteckiej, członkiem Komitetu Zarządzającego Odległego Czytania Europejskiej Historii Literatury w finansowanym przez UE programie Europejskiej Współpracy Naukowej i Technologicznej (COST Action CA16204) oraz członkiem rady redakcyjnej „International Journal of Digital Humanities" (Springer Nature). Jego zainteresowania badawcze obejmują zarządzanie informacjami i wiedzą, informacje biznesowe, rozwój przedsiębiorczości w szkoleniach w zakresie LIS i humanistyki cyfrowej.

\section{Informacje o żegludze na Węgrzech -}

\section{perspektywa diachronicznie zorientowanej}

\section{biblioteki w przeszłości, teraźniejszości}

\section{i przyszłości}

DOI: http://dx.doi.org/10.12775/FT.2019.003

łowa kluczowe: system treści; bazy danych; Węgry; informacyjna usługa biblioteki; projekt badawczy; żegluga

treszczenie. Cel: Celem tego artykułu jest wprowadzenie ewolucyjnego procesu narzędzi usług informacyjnych wykorzystywanych w bibliotekach poprzez system węgierskich źródeł informacji o żegludze. W pierwszej części opisujemy możliwy model gromadzenia, identyfikacji, analizy i publikacji węgierskiej literatury naukowej na temat żeglugi. W następnej części opisujemy obecną sytuację na Węgrzech, szczególnie w odniesieniu do treści dostępnych online za darmo, opublikowanych przez organy administracji publicznej oraz organizacje zawodowe i pozarządowe. Wreszcie omawiamy możliwe przyszłe kierunki rozwoju. Metoda badawcza: Nasze badania opierają się na literaturze naukowej, profesjonalnych konsultacjach, własnym zbiorze danych i doświadczeniach. Nasza praca, szczególnie w zakresie identyfikacji i wykorzystania dokumentów oraz nowoczesnych aplikacji komunikacyjnych, opiera się w dużej mierze na selekcji i ocenie przeprowadzanej w trakcie informacyjnej 
usługi biblioteki, podejściu systemowym i poszukiwaniu połączeń. Chcieliśmy wykorzystać w artykule bibliograficzne odniesienia, ale w przypadkach, w których nie znaleziono takich źródeł i było to konieczne do zrozumienia tego punktu, wymieniliśmy węgierskie wpisy bibliograficzne. Wyniki/Wnioski: Rozwój systemów usług informacyjnych związanych z żeglugą i ukierunkowanych na bieżące wydarzenia jest nie do pomyślenia bez angażowania najnowszych innowacji informatycznych, współpracy różnych dziedzin oraz sieci wsparcia Unii Europejskiej. Przyszłością są usługi zapewniające zagregowane wyszukiwanie według wielu kryteriów. Inne narody mogą czerpać inspirację z analizy krzywej rozwojowej Węgier i trendów, aby zaspokoić zarówno naukowe, jak i codzienne potrzeby źródeł w terenie; ten dokument może również pomóc w powiązaniu rozwoju Węgier z dalszymi międzynarodowymi systemami informacyjnymi. 


\section{Péter Kiszl}

Eötvös-Loránd-Universität in Budapest, Ungarn. Philosophische Fakultät e-mail: kiszl.peter@btk.elte.hu

ORCID ID: 0000-0003-2992-295X

Dr. habil. Péter, Kiszl, Bibliothekar und Wirtschaftswissenschaftler, außerordentlicher Professor an der Eötvös-Loránd-Universität in Budapest (Ungarn), Direktor des Instituts für Bibliothekswissenschaften und Wissenschaftliche Information (LIS), Leiter der Abteilung für Informationswissenschaft, Direktor des Doktorandenprogramms LIS, Leiter der Lizentiats- und Magisterstudien LIS, Direktor des Zentrums für Digitale Geisteswissenschaften, Vorsitzender des Aufsichtsrats bei der Stiftung der Universitätsbibliothek, Mitglied des Verwaltungskomitees des sog. distant reading in der Europäischen Literaturgeschichte, finanziert von der EU im Rahmen der Europäischen Zusammenarbeit auf dem Gebiet der Wissenschaft und Technologie (COST Action CA16204), sowie Mitglied des Redaktionsrats „International Journal of Digital Humanities“ (Springer Nature). In sein Forschungsinteresse fallen die Informations- und Wissensverwaltung, Geschäftsinformationen, Entwicklung des Unternehmertums in Schulungen im LIS-Bereich und der digitalen Geisteswissenschaften.

\section{Angaben zu Schifffahrt in Ungarn -}

\section{Perspektive einer diachron orientierten}

\section{Bibliothek in der Vergangenheit, Gegenwart}

\section{und Zukunft}

DOI: http://dx.doi.org/10.12775/FT.2019.003

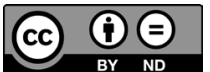

Dieser Text wird unter der Creative Commons-Lizenz Namensnennung-Keine Bearbeitungen 4.0 International (CC BY-ND 4.0) veröffentlicht.

tichworte: Inhaltssystem; Datenbanken; Ungarn; Informationsdienste der Bibliothek; Forschungsprojekt; Schifffahrt

usammenfassung. These/Ziel: Der Beitrag führt in einen evolutionären Prozess der Werkzeuge ein, die für die Informationsdienste der Bibliotheken mithilfe eines Systems von ungarischen Informationsquellen zur Schifffahrt vorbereitet werden. Im ersten Teil schildern wir das Beispiel von Sammlung, Identifizierung, Analyse und Publikation der ungarischen Forschungsliteratur zur Schifffahrt. Der darauffolgende Teil bezieht sich auf die gegenwärtige Situation in Ungarn insbesondere in Hinblick auf die Inhalte, die online frei zugänglich sind und von den öffentlichen Verwaltungsorganen sowie Berufs- und Nichtregierungsorganisationen veröffentlicht wurden. Anschließend zeigen wir die möglichen Entwicklungswege in Zukunft. Forschungsmethode: Unsere Untersuchung stützt sich auf die Fachliteratur, Expertenberatung, die eigene Datenbank und Erfahrungen. Unsere Arbeit, insbesondere im Bereich 
der Identifizierung und Benutzung von Dokumenten und modernen Kommunikationsapplikationen, und beruht größtenteils auf der Auswahl und Bewertung, die bei der Bearbeitung von Informationsaufgaben einer Bibliothek erfolgten, auf dem Systemansatz und der Suche nach Verbindungen. Im Beitrag wollten wir bibliografische Bezugspunkte nutzen, aber in solchen Fällen, wo derartige Quellen nicht gefunden wurden, aber für das Verständnis der genannten Frage notwendig waren, tauschten wir die ungarischen bibliografischen Einträge. Ergebnisse/Schlussfolgerungen: Die Entwicklung der Systeme der Informationsdienste, die mit der Schifffahrt verbunden sind und sich auf die aktuellen Ereignisse beziehen, ist kaum denkbar ohne Miteinbeziehung von den neuesten Informationsinnovationen, der Zusammenarbeit verschiedener Fachbereiche sowie der Erstellung vom Unterstützungsnetz seitens der EU. Die Zukunft bilden jene Dienste, die eine aggregierte Suche nach Kriterien bereitstellen. Andere Nationen können aus der Analyse der Entwicklungskurve Ungarns und der Trends schöpfen, um sowohl die wissenschaftlichen als auch die alltäglichen Quellenbedürfnisse zu befriedigen; dieser Beitrag zielt auch darauf, die Entwicklung Ungarns mit den weiteren internationalen Informationssystemen zu verbinden. 